University of Nebraska - Lincoln

DigitalCommons@University of Nebraska - Lincoln

U.S. Environmental Protection Agency Papers

U.S. Environmental Protection Agency

2006

Waterfowl-habitat associations during winter in an urban North Atlantic estuary

Richard A. McKinney

US Environmental Protection Agency, mckinney.rick@epa.gov

Scott R. McWilliams

University of Rhode Island

Michael A. Charpentier

Computer Sciences Corporation

Follow this and additional works at: https://digitalcommons.unl.edu/usepapapers

McKinney, Richard A.; McWilliams, Scott R.; and Charpentier, Michael A., "Waterfowl-habitat associations during winter in an urban North Atlantic estuary" (2006). U.S. Environmental Protection Agency Papers. 105.

https://digitalcommons.unl.edu/usepapapers/105

This Article is brought to you for free and open access by the U.S. Environmental Protection Agency at DigitalCommons@University of Nebraska - Lincoln. It has been accepted for inclusion in U.S. Environmental Protection Agency Papers by an authorized administrator of DigitalCommons@University of Nebraska - Lincoln. 


\title{
Waterfowl-habitat associations during winter in an urban North Atlantic estuary
}

\author{
Richard A. McKinney ${ }^{a, *}$, Scott R. McWilliams ${ }^{b}$, Michael A. Charpentier \\ ${ }^{a}$ US Environmental Protection Agency, Office of Research and Development, National Health and Environmental Effects Research \\ Laboratory, Atlantic Ecology Division, 27 Tarzwell Drive, Narragansett, RI 02882, USA \\ ${ }^{\mathrm{b}}$ Department of Natural Resources Science, University of Rhode Island, Kingston, RI 02881, USA \\ 'Computer Sciences Corporation, 27 Tarzwell Drive, Narragansett, RI 02882, USA
}

\section{A R T I C L E I N F O}

\section{Article history:}

Received 14 July 2005

Received in revised form

8 March 2006

Accepted 5 April 2006

Available online 24 May 2006

Keywords:

Coastal marine habitats

Wintering waterfowl

AIC

Habitat alteration

Narragansett Bay

Wildfowl

\begin{abstract}
A B S T R A C T
Coastal habitats near urban centres in North Atlantic estuaries often support substantial numbers of wintering waterfowl, but little is known of the effects of landscape setting and urbanisation on habitat use. We conducted surveys of waterfowl at 32 wintering sites in Narragansett Bay, Rhode Island, to identify characteristics that may influence habitat use. Sites were chosen along a gradient of urbanisation and reflected the dominant habitat types used by waterfowl in the Bay. Mean waterfowl abundance was $206.7 \pm 209.5$ birds per site, and sites in the inner part of the estuary had higher overall waterfowl abundances $\left(r^{2}=0.40, p=0.021\right)$. Species richness ranged from 3.2 to 13.0 and decreased with increasing hunting activity $\left(r^{2}=0.36, p=0.040\right)$. Hunting activity and habitat characteristics (e.g., latitude, shoreline configuration, prey density) explained $13-27 \%$ of the variation in waterfowl abundance and species richness among sites, but landscape characteristics (e.g., surrounding residential development, vegetated land, or wetland surrounding the sites and the extent of wetland edge) explained an additional 1-26\%. The landscape characteristics extent of adjacent residential development and vegetated upland were the most common variables entering into the models; most species were more abundant at sites with more adjacent vegetated upland and less adjacent residential development. Our results suggest that landscape setting may be influencing the distribution of wintering waterfowl, and should be considered when developing strategies for the conservation for these species in urban North Atlantic estuaries.
\end{abstract}

Published by Elsevier Ltd.

\section{Introduction}

Coastal habitats are being increasingly impacted by urbanisation, both through direct loss and the indirect effects of human activities within the habitats or the adjoining watershed (Hinrichsen, 1996; Michael et al., 1998; Kennish, 2002). These effects are particularly acute in North Atlantic estuaries, many of which contain or are near urban centres. In addition to being highly desirable areas for development, coastal habitats are essential to the ecology of many species of estuarine wildlife in that they provide structure and life support functions to critical life stages and aid in the protection and development of many species (Collopy and Bildstein, 1987; Colwell, 1993; Chavez-Ramirez and Slack, 1995). In order to adequately assess the costs and benefits of developing or protecting coastal lands, we need to know more about the effects of human-induced alteration of these areas. Many studies have investigated the impact of these alterations on

* Corresponding author: Tel.: +1 401782 3133; fax: +1 4017823030.

E-mail address: mckinney.rick@epa.gov (R.A. McKinney).

0006-3207/\$ - see front matter. Published by Elsevier Ltd.

doi:10.1016/j.biocon.2006.04.002 
the degradation of coastal habitats themselves and its effects on economically important fish and shellfish populations (Neves and Angermeier, 1990; Ambrose and Meffert, 1999; Vanderklift and Jacoby, 2003), but fewer have focused on the effects on estuarine wildlife such as birds and mammals (Madsen and Fox, 1995; Perry and Deller, 1996; West et al., 2002; Le V Dit Durell et al., 2005).

Many species of waterfowl (ducks, geese, and swans) use coastal habitats at certain stages in their life histories, and North Atlantic estuaries often support substantial numbers of wintering sea ducks, dabbling ducks, and diving ducks (Bellrose, 1980; Gordon et al., 1989; Elkins and Lynch, 1997; Krasnov et al., 2004). Particularly in heavily developed areas, patterns of habitat use by wintering waterfowl may provide insights into the habitat value of coastal areas. For example, if it is found that waterfowl will avoid using areas subject to indirect or proximal human disturbance, the value of that habitat may be diminished in the context of conservation and management of wintering waterfowl populations. A number of studies have examined the effects of direct human disturbance on waterfowl, but most of these have concentrated on managed impoundments, refuges, and protected areas (Davidson and Rothwell, 1993; Madsen, 1995; Conomy et al., 1998; Evans and Day, 2001). Coastal areas near urban centres also provide habitat for wintering waterfowl, and these have been less studied although they may be subject to greater pressure from urbanisation (Clausen et al., 1998; Clergeaua et al., 2006). Even though a habitat itself may remain intact and be protected, its landscape setting can be altered by development or human activity within its watershed.

The landscape setting of a habitat has been shown to influence bird distribution and abundance; for example, studies on passerines have identified landscape heterogeneity (Roth, 1976; Bennett and Ford, 1997), extent of urbanisation or agriculture (Miller and Cale, 2000; Soderstrom et al., 2001), and edge density (Fletcher and Koford, 2002) as landscape characteristics that may influence habitat utilisation. However, other studies have suggested the importance of so-called structural or habitat characteristics in determining habitat use (Esselink et al., 2000; Adamik et al., 2003; Ravenscroft and Beardall, 2003). For waterfowl, important habitat characteristics may include protection from exposure to harsh winds and cold, shoreline extent, the presence of adequate food, and habitat area (Christiansen and Low, 1970; Sanderson, 1980).

In this study, we examined waterfowl use of coastal habitats along a gradient of human disturbance. We investigated the effects of landscape setting on waterfowl wintering in Narragansett Bay, RI, USA, an estuary in an urban setting that has a variety of habitat types surrounded by different amounts of residential and natural lands. Using a nested modeling approach with both habitat and landscape characteristics, we compared waterfowl habitat use along a gradient of human land use at 32 study sites that represent the predominant habitat types in the Bay: shallow coves, salt marsh-dominated inlets, open water and rocky headlands. Hunting activity was included in all models because this form of direct human disturbance was pervasive across all of our sites, and has been demonstrated to influence habitat use by wintering waterfowl (Owen, 1993; Madsen, 1998a,b). Previ- ous studies identified four waterfowl species assemblages that use these habitats in the Bay (McKinney, 2004), and we developed models for each assemblage and for all waterfowl as a group.

We evaluated models using an Information Theoretic Approach that allows us to identify a best model for each species assemblage, and also to identify which habitat or landscape characteristics may best explain waterfowl abundance (Anderson et al., 2001; Burnham and Anderson, 2002). Our specific objectives were to (1) identify the best-fit model for explaining waterfowl abundance based on habitat and landscape characteristics for each waterfowl species assemblage and all waterfowl in Narragansett Bay, (2) identify specific characteristics that may be influencing habitat utilisation, and (3) investigate whether landscape setting is influencing habitat use of wintering waterfowl in an urban estuary.

\section{Methods}

\subsection{Study sites}

We selected study sites from known waterfowl wintering habitats within Narragansett Bay (Fig. 1). The average waterfowl density in Narragansett Bay is 39 birds per square kilometer, which is comparable to Boston Harbor, USA to the north (36 birds per square kilometer), but less than Chesapeake Bay, USA to the south (55 birds per square kilometer; McKinney, 2004). Sites were chosen along a gradient of human land use intensity (i.e. urban to suburban to rural) and consisted of shallow coves (mean depth $<1 \mathrm{~m} ; n=8$ ), salt marsh-dominated inlets (wetland/water area $>0.2 ; n=7$ ), open water (embayments with mean depth $>1 \mathrm{~m} ; n=12$ ), and rocky headlands (determined by visual inspection; $n=5$ ). Study sites differed in area (range 6.3-1204 ha; mean $=99.7 \mathrm{ha}$ ), mean depth (range 0.2-5.8 m [mean low water]; mean $=2.2 \mathrm{~m}$ ), and perimeter (range $1.1-40 \mathrm{~km}$; mean $=7.5 \mathrm{~km}$ ) typical of eastern North Atlantic estuaries (Conley et al., 2000; Roman et al., 2000).

\subsection{Waterfowl surveys}

Survey data were collected during the winters (January-February inclusive) of 2001-2003 using a 32-60 × spotting scope or $10 \times 50$ binoculars. At each site we were positioned so we could observe the entire surface of the site from the land. Sites were surveyed twice during the survey period (for a total of 2 samples per site per year and 6 samples per site per year over the course of the study) on randomly chosen days and at randomly chosen times of day. The number and species of waterfowl present at the sites was recorded during each survey.

\subsection{Habitat and landscape measurements}

Habitat and land-use characteristics were developed using Geographic Information System (GIS) topographic databases. GIS data (e.g., shorelines, land use and land cover) were obtained from the Rhode Island Geographic Information System (RIGIS) and were processed using Environmental Systems Research Institute (ESRI) ARC GIS software (Redlands, CA). 


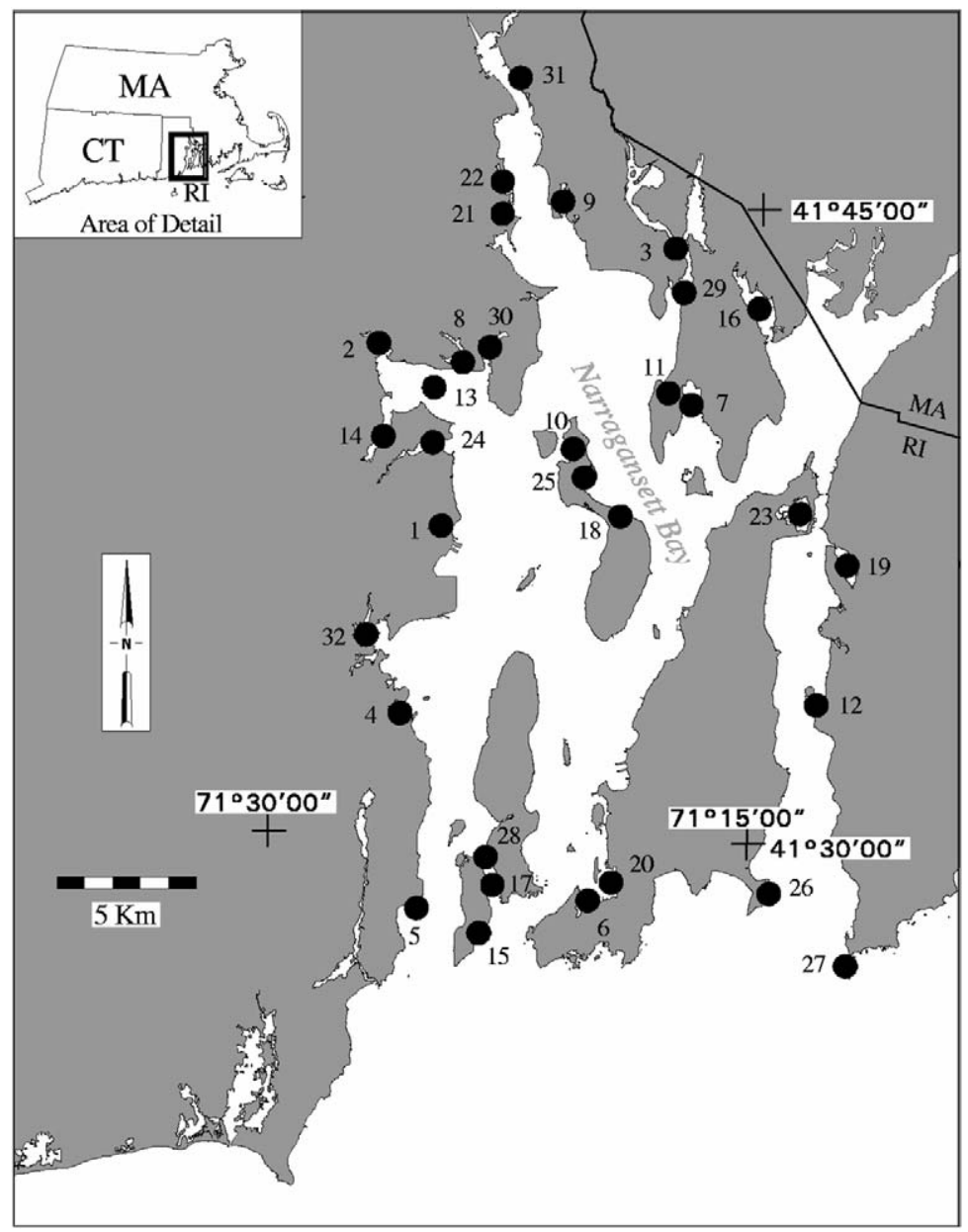

Fig. 1 - Location of study sites surveyed for waterfowl in Narragansett Bay, Rhode Island USA 2001-2003. 1, Allen Harbor; 2, Apponaug Cove; 3, Barrington River; 4, Bissel Cove; 5, Bonnet Point; 6, Brenton Cove; 7, Bristol Harbor; 8, Brush Neck Cove; 9, Bullocks Cove; 10, Coggeshell Cove; 11, Colt State Park; 12, Fogland Point; 13, Greenwich Bay; 14, Greenwich Cove; 15, Hull Cove; 16, Kickemuit River; 17, Mackerel Cove; 18, Nag Pond; 19, Nanaquaket Pond; 20, Newport Harbor; 21, Passeonkquis Cove; 22, Pawtuxet Cove; 23, Portsmouth Cove; 24, Potowomut River; 25, Potter Cove; 26, Sachuest Point; 27, Sakonnet Point; 28, Sheffield Cove; 29, Warren River; 30, Warwick Cove; 31, Watchemoket Cove; 32, Wickford Harbor.

Shoreline data were derived from $15 \mathrm{~min}$ (1:24,000 scale) United States Geological Survey (USGS) topographic maps, land use and land cover data were developed from 1995 aerial photography (1:24,000 scale) coded to Anderson modified level 3 (Anderson et al., 1976) to one half-acre (0.1 ha) minimum polygon resolution. The shoreline data were used to determine the latitude (LATD; distance of the site in nautical miles from $41^{\circ} \mathrm{N}$ latitude), area (AREA), and perimeter of the sites. Shoreline configuration (SHRL) is the ratio of the perimeter of a site to the circumference of a circle of area equal to that of the site (Wetzel, 1975, p. 31). The land use and land cover data layer was used to calculate the proportion of land use within a $100 \mathrm{~m}$ buffer surrounding each site. The area of various land use types was used to calculate percent vegetated land (VEGL), residential land (RESL), and wetland (WLAR) within the $100 \mathrm{~m}$ buffer of each site. The ratio of the area of each land use type within the $100 \mathrm{~m}$ buffer to the perimeter of the sites was used to calculate vegetated edge, residential edge and wetland edge (W/ED). We repeated this analysis for the northwest portion of the $100 \mathrm{~m}$ buffer (the area con- tained within lines drawn at headings of $270^{\circ}$ and $360^{\circ}$ from the location within the site where the majority of the waterfowl were observed), which corresponded to the prevailing direction of winter winds in Narragansett Bay. We calculated natural buffer from wind as the proportion of vegetated land (forest and shrub) within this segment that could provide shelter from prevailing winds, and man-made buffer from wind as the proportion of developed land (residential, commercial, and industrial) within the segment. These two variables were summed to calculate total buffer from wind (BUFT). Habitat and landscape characteristics from single measurements were used in constructing habitat models.

We used grab sampling to measure the abundance of benthic invertebrates that could serve as prey for shallow cove, open water, and rocky headland waterfowl species. Sub-tidal sample locations within the sites were chosen at random using a probability-based random sampling protocol (Paul et al., 2003). A total of 10 samples were obtained from each site at the onset of the project during the winter of 2001 using a Ponar grab sampler, which samples an $81 \mathrm{~cm}^{2}$ area of the 
sediment surface down to a depth of $2-5 \mathrm{~cm}$ (Klemm et al., 1990). Samples were passed through a $0.5 \mathrm{~mm}$ sieve and immediately sorted, counted, and measured. Abundances were calculated as the average of 10 grabs. Biomass of available soft tissue for each was calculated using existing allometric length-weight relationships (McKinney et al., 2004). We calculated productivity at each site using known productivity to biomass relationships (Robertson, 1979), and used these values along with species-specific tissue energy densities to estimate site energy density. Species were aggregated by phylum to calculate available crustacean energy density (PREC), available mollusc energy density (PREM), and all available prey energy density.

An index of waterfowl hunting (range: 1-5) was developed for each site using the best available data on hunting trends in the Bay (C. Allin, Rhode Island Division of Fish and Wildlife, personal communication) and observations made during sampling events. Sites at which waterfowl hunting was prohibited by state waterfowl hunting regulations were assigned an index value of 1 . Those at which hunting was allowed, but which had only occasional hunting activity documented were assigned a value of 3 . Sites where hunting was allowed and where regular hunting activity was documented and observed during waterfowl surveys were assigned a value of 5 . Other sites were assigned intermediate values depending on the level of hunting activity.

\subsection{Statistical analysis}

We aggregated waterfowl abundance data into four species assemblages based on life histories (e.g., Bellrose, 1980; Gauthier, 1993) and previous studies in Narragansett Bay (Table 1). Waterfowl abundance was modeled instead of waterfowl density because we wanted to treat site area as a habitat characteristic in our models, since habitat area could conceivably be of conservation and management concern. Species richness was the number of waterfowl species observed at a site. Infrequently observed ducks (e.g., king eider Somateria spectabilis or tufted duck Aythya fuligula) were not included in estimates of species richness or abundance. Abundance data were tested for evidence of year effects by calculating the species percent composition, or the percentage of all waterfowl that consisted of a given species assemblage (e.g., rocky head- land species comprised $8.8 \%$ of all waterfowl during 2001). Because the variation in percent composition ranged from $2.0 \%$ to $4.7 \%$ for all species assemblages, and was similar among years (ANOVA; $F_{2} \geqslant 0.001, p>0.50$ ), we did not de-trend the data. Abundances were pooled from 2001 to 2003, and square-root transformed prior to significance testing (but not prior to model development) to improve homogeneity of variances and normality (Fowler et al., 1998, p. 87).

Habitat characteristics that were highly correlated $(r>0.7)$ were not included in habitat association models. Specifically, prey energy density of all prey was positively correlated with prey energy density of molluscs $(r=0.88, p<0.01)$ and was eliminated, natural buffer from wind and man-made buffer from wind were positively correlated with total buffer from wind $(r>0.76, p<0.01)$ and were eliminated, and vegetated edge and residential edge were negatively correlated with wetland edge $(r>0.80, p<0.01)$. For all associated habitat characteristics only the latter was included in the habitat association models. The remaining characteristics were classified into two groups: habitat characteristics which included latitude (LATD), area (AREA), shoreline configuration (SHRL), prey energy density of molluscs (PREM), and prey energy density of crustaceans (PREC); and landscape characteristics which included residential land-use (RESL), proportion of vegetated land (VEGL), total buffer from wind (BUFT), proportion of wetland (WLAR), and wetland edge (W/ED). Habitat characteristics were transformed as required to improve homogeneity of variances and normality. We used Spearman rank correlation analysis to examine the relationship between individual characteristics and waterfowl abundance.

We used multiple linear regression, with waterfowl abundance (birds/day/site) of four species assemblages and also species richness as the dependent variables, to construct models to explain habitat use based on habitat and landscape characteristics. A nested approach was used because we expected habitat characteristics such as site location, area, and prey abundance to explain much of the variation in waterfowl abundance (e.g., Goudie and Ankney, 1988; Perry and Deller, 1996; Gordon et al., 1998). We were also interested in whether urbanisation-related characteristics explained additional variation in habitat use. We therefore developed models based on habitat characteristics, or those intrinsic to the site, and examined whether the addition of landscape

Table 1 - Duck species assemblages at wintering sites in Narragansett Bay, RI, USA, 2001-2003

\begin{tabular}{llll} 
Shallow cove $^{\mathrm{a}}$ & \multicolumn{1}{c}{ Marsh $^{\mathrm{b}}$} & \multicolumn{1}{c}{ Open water $^{\mathrm{c}}$} & Rocky headland $^{\mathrm{d}}$ \\
\hline Bufflehead & American black duck & Common goldeneye & Harlequin duck \\
Canvasback & Mallard & Barrow's goldeneye & Common eider \\
Hooded merganser & American wigeon & Scoter spp. & Long-tailed duck \\
& Gadwall & Red-breasted merganser & \\
& & Scaup spp. & \\
& & & \\
& & & \\
\end{tabular}

Ducks were categorized based on life histories and previous studies of waterfowl distribution in Narragansett Bay.

a Scientific names: bufflehead Bucephala albeola, canvasback Aythya valisineria, hooded merganser Mergus cucullatus.

b American black duck Anas rubripes, mallard Anas platyrhynchos, American wigeon Anas americana, gadwall Anas strepera.

c Common goldeneye Bucephala clangula, Barrow's goldeneye Bucephala islandica, scoter Melanitta spp., long-tailed duck Clangula hyemalis,

red-breasted merganser Mergus serrator, scaup Aythya spp.

d Harlequin duck Histrionicus histrionicus, common eider Somateria mollissima. 
characteristics, or those that could come under management action, improved the models. To do this, we first determined the best model(s) for explaining waterfowl abundance based on habitat characteristics (LATD, AREA, SHRL, PREM, and PREC) and an index of hunting activity (HUNT). Our rationale for separating hunting disturbance from other landscape characteristics was that this form of disturbance is not necessarily related to urbanisation and land use around the sites, i.e., hunting disturbance can and in many cases is more likely to occur in relatively undisturbed habitats. Best habitat models were evaluated using small sample Akaike Information Criteria $\left(\mathrm{AIC}_{\mathrm{c}}\right)$, which accounts for biases that might arise from relatively small sample size (Burnham and Anderson, 2002, p. 66). We then added landscape characteristics to the best habitat models, which were also evaluated using AIC $_{c}$. Finally, we tested the best habitat model against the best habitat + landscape model by computing $\mathrm{AIC}_{\mathrm{c}}$ differences $\left(\Delta \mathrm{AIC}_{\mathrm{c}}=\mathrm{AIC}_{\mathrm{ci}}-\mathrm{AIC}_{\mathrm{cmin}}\right.$; Burnham and Anderson, 2002, pp. 70-72). Statistical analyses were performed with SAS for Windows ver. 6.12 (SAS Institute, Inc., Carey, NC, USA).

We computed Akaike weights for each habitat + landscape model to determine the best models (Burnham and Anderson,
2002, pp. 75-77). The relative importance $\left(w_{+}(j)\right)$ of each landscape characteristic was determined by summing the Akaike weights of all models that included this characteristic (Burnham and Anderson, 2002, pp. 167-169). Relative importance values provide a means to incorporate selection uncertainty in the evaluation of a set of characteristics, and larger values of $w_{+}(j)$ indicate that a particular characteristic may be a better predictor variable (Burnham and Anderson, 2002, p. 167).

\section{Results}

In general, open water species were the most abundant assemblage at most study sites, followed by marsh ducks and shallow cove species (Table 2). Mean waterfowl abundance was $206.7 \pm 209.5$ birds per site per day $(n=6)$, and species richness averaged $6.47 \pm 2.33$ species per site per day $(n=6)$. Waterfowl abundance increased with increasing latitude, with inner Bay sites having higher abundances than those located near the mouth of the Bay $\left(r^{2}=0.40, p=0.021\right)$. Degree of hunting tended to decrease with increasing latitude, but not significantly $\left(r^{2}=0.32, p=0.068\right)$. Total waterfowl abundance $\left(r^{2}=0.40, p=0.022\right)$ and marsh duck abundance

Table 2 - Abundance (number of birds per site \pm SE) of all waterfowl and four species assemblages, and species richness of waterfowl at wintering sites in Narragansett Bay, RI, USA, 2001-2003

\begin{tabular}{|c|c|c|c|c|c|c|}
\hline Site & ALL & SHC & OPW & RKH & MAR & SPR \\
\hline Allen Harbor & $96.2 \pm 39.2$ & $14.4 \pm 3.8$ & $80.2 \pm 36.4$ & 0.0 & 0.0 & $3.2 \pm 1.0$ \\
\hline Apponaug Cove & $559.3 \pm 304.7$ & $27.0 \pm 3.3$ & $20.0 \pm 0.6$ & 0.0 & $168.0 \pm 84.2$ & $9.0 \pm 2.9$ \\
\hline Barrington River & $49.8 \pm 16.3$ & $26.2 \pm 7.0$ & $1.3 \pm 0.5$ & 0.0 & $15.2 \pm 7.1$ & $5.3 \pm 1.6$ \\
\hline Bissel Cove & $68.2 \pm 27.8$ & $9.0 \pm 2.4$ & $43.4 \pm 21.1$ & 0.0 & $8.6 \pm 4.3$ & $6.0 \pm 2.0$ \\
\hline Bonnet Point & $10.3 \pm 0.8$ & 0.0 & $9.5 \pm 2.0$ & $0.5 \pm 0.4$ & 0.0 & $3.3 \pm 1.1$ \\
\hline Bristol Harbor & $179.7 \pm 84.2$ & $12.9 \pm 2.4$ & $25.1 \pm 9.7$ & 0.0 & $27.0 \pm 6.5$ & $9.0 \pm 2.9$ \\
\hline Brenton Cove & $244.2 \pm 79.8$ & $6.9 \pm 1.9$ & $64.0 \pm 29.1$ & 0.0 & $93.5 \pm 44.8$ & $5.1 \pm 1.6$ \\
\hline Brush Neck Cove & $320.9 \pm 177.1$ & $24.4 \pm 3.6$ & $30.3 \pm 19.2$ & 0.0 & $96.8 \pm 56.6$ & $10.3 \pm 3.3$ \\
\hline Bullocks Cove & $511.6 \pm 163.3$ & $34.9 \pm 9.5$ & $61.1 \pm 45.7$ & 0.0 & $136.8 \pm 91.5$ & $7.6 \pm 2.6$ \\
\hline Colt State Park & $214.5 \pm 30.7$ & $13.9 \pm 8.1$ & $27.5 \pm 12.7$ & 0.0 & $134.5 \pm 10.2$ & $6.3 \pm 2.0$ \\
\hline Coggeshell Cove & $81.4 \pm 5.4$ & $37.3 \pm 15.3$ & $37.8 \pm 25.1$ & 0.0 & $3.0 \pm 0.4$ & $7.0 \pm 2.3$ \\
\hline Fogland Point & $76.5 \pm 8.6$ & $14.0 \pm 0.8$ & $11.1 \pm 9.0$ & 0.0 & $47.5 \pm 2.0$ & $3.6 \pm 1.3$ \\
\hline Greenwich Bay & $132.4 \pm 63.8$ & $13.9 \pm 7.5$ & $75.3 \pm 38.7$ & 0.0 & $40.8 \pm 51.0$ & $6.0 \pm 2.0$ \\
\hline Greenwich Cove & $472.4 \pm 154.3$ & $1.0 \pm 0.7$ & $307.0 \pm 227.7$ & 0.0 & $61.8 \pm 31.4$ & $9.1 \pm 2.9$ \\
\hline Hull Cove & $56.5 \pm 78.7$ & $16.9 \pm 5.7$ & $33.1 \pm 17.8$ & 0.0 & $4.6 \pm 4.1$ & $5.0 \pm 1.6$ \\
\hline Kickemuit River & $87.9 \pm 35.8$ & 0.0 & $75.3 \pm 39.2$ & 0.0 & $7.0 \pm 3.3$ & $5.3 \pm 1.6$ \\
\hline Mackerel Cove & $66.6 \pm 32.4$ & $4.9 \pm 0.7$ & $52.5 \pm 24.1$ & 0.0 & $7.8 \pm 6.3$ & $5.0 \pm 2.3$ \\
\hline Nag Pond & $12.0 \pm 7.4$ & $4.5 \pm 3.7$ & 0.0 & 0.0 & $7.5 \pm 3.7$ & $2.9 \pm 1.0$ \\
\hline Nanaquaket Pond & $219.5 \pm 151.6$ & $21.5 \pm 10.2$ & $2.5 \pm 2.0$ & 0.0 & $55.0 \pm 45.0$ & $5.1 \pm 1.6$ \\
\hline Newport Harbor & $87.1 \pm 28.4$ & $2.3 \pm 0.5$ & $56.7 \pm 26.3$ & $2.0 \pm 0.7$ & $11.8 \pm 5.8$ & $4.3 \pm 2.3$ \\
\hline Passeonkquis Cove & $132.0 \pm 14.7$ & $8.5 \pm 6.9$ & $32.5 \pm 26.6$ & 0.0 & $75.5 \pm 56.0$ & $9.1 \pm 2.9$ \\
\hline Potter Cove & $248.1 \pm 40.0$ & $52.1 \pm 6.6$ & $100.0 \pm 29.4$ & 0.0 & $24.2 \pm 9.8$ & $7.0 \pm 2.3$ \\
\hline Potowomut River & $97.2 \pm 87.8$ & $43.9 \pm 11.5$ & $6.0 \pm 8.5$ & 0.0 & 0.0 & $4.3 \pm 1.3$ \\
\hline Portsmouth Cove & $177.6 \pm 72.3$ & $59.5 \pm 16.2$ & $5.2 \pm 2.3$ & 0.0 & $47.4 \pm 23.9$ & $4.1 \pm 1.3$ \\
\hline Pawtuxet Cove & $191.3 \pm 78.1$ & $14.0 \pm 3.8$ & $140.3 \pm 103.9$ & 0.0 & $8.7 \pm 4.8$ & $7.9 \pm 2.6$ \\
\hline Sachuest Point & $239.4 \pm 80.1$ & $30.3 \pm 3.1$ & $87.5 \pm 20.4$ & $96.1 \pm 33.4$ & $25.8 \pm 4.8$ & $13.0 \pm 1.1$ \\
\hline Sakonnet Point & $210.1 \pm 86.7$ & $2.3 \pm 1.0$ & $17.1 \pm 3.4$ & $190.8 \pm 90.1$ & 0.0 & $6.3 \pm 2.0$ \\
\hline Sheffield Cove & $44.4 \pm 6.2$ & $17.1 \pm 0.7$ & $12.8 \pm 5.9$ & 0.0 & $10.0 \pm 8.2$ & $7.1 \pm 2.3$ \\
\hline Warwick Cove & $188.3 \pm 76.8$ & $2.1 \pm 0.5$ & $39.9 \pm 18.2$ & 0.0 & $21.7 \pm 10.8$ & $6.3 \pm 2.0$ \\
\hline Warren River & $90.5 \pm 36.8$ & $60.2 \pm 20.5$ & $21.8 \pm 10.7$ & 0.0 & $8.2 \pm 3.7$ & $6.1 \pm 2.0$ \\
\hline Watchemoket Cove & $1053.3 \pm 591.2$ & $19.5 \pm 5.1$ & $603.1 \pm 490.6$ & 0.0 & $90.5 \pm 55.2$ & $10.0 \pm 3.3$ \\
\hline Wickford Harbor & $399.0 \pm 163.1$ & $45.3 \pm 27.9$ & $109.6 \pm 50.1$ & 0.0 & $175.4 \pm 115.2$ & $7.1 \pm 2.3$ \\
\hline Total all sites & $6613 \pm 4369$ & $626 \pm 297$ & $2188 \pm 2266$ & $289 \pm 216$ & $1415 \pm 1210$ & - \\
\hline
\end{tabular}

ALL, all waterfowl species combined, including geese and swans; SHC, shallow cove species; OPW, open water species; RKH, rocky headland species; MAR, marsh ducks; SPR, species richness. Species included in waterfowl assemblages are listed in Table 1. 
$\left(r^{2}=0.44, p=0.013\right)$ decreased with hunting activity, whereas species richness increased with a decrease in hunting activity across sites $\left(r^{2}=0.36, p=0.040\right)$. Species richness ranged from 3.2 at Allen Harbor, a mid-bay shallow cove site, to 13.0 at Sachuest Point, a rocky headland site at the mouth of the Bay.

Habitat and landscape characteristics differed considerably among sites; for example, site area averaged 102 ha but ranged from 6.3 to 1200 ha, and both mollusc and crustacean prey energy density ranged over more than three orders of magnitude (Table 3a). The proportion of residential land (RESL) and vegetated land (VEGL) bordering the sites ranged from 0.0 to 0.76 , but on average was 0.313 for residential land and 0.215 for vegetated land (Table $3 b$ ). The extent of natural or man-made wind buffer on the northwest border of a site ranged from complete $(\mathrm{BUFT}=1.000)$ to none $(\mathrm{BUFT}=0.000)$, and averaged 0.563 (Table $3 \mathrm{~b}$ ). The area of wetland bordering the sites averaged $4.6 \mathrm{ha}$, although more than half the sites had less than 5 ha of adjoining wetland.

Habitat models explained some of the variance in species richness and abundance of all waterfowl, and rocky headland and shallow cove species $\left(r^{2}: 0.23-0.35\right)$, but explained little of the variance in abundance of marsh ducks and open water species (Table 4). Latitude (LATD) had the highest relative importance of the characteristics considered in the habitat models, followed by shoreline configuration and mollusc prey density (Table 5).

Adding landscape characteristics improved the models considerably $\left(\Delta \mathrm{AIC}_{\mathrm{c}}>2\right)$ for all species except for marsh ducks (Table 4). Landscape characteristics explained an additional $1-26 \%$ of the variation in waterfowl abundance when added to the habitat models (Table 4). Surrounding residential land, surrounding vegetated land, and wetland edge most frequently contributed to the additional variance explained by the habitat + landscape models (Table 6).

\section{Discussion}

Waterfowl abundance at our sites in Narragansett Bay was less than that previously reported for nearby estuaries. For example, the mean abundance of shallow cove and open water species at our sites was about 20 times less than that reported for several similarly sized habitats located on the New Hampshire, USA coastline approximately $200 \mathrm{~km}$ to the north (964 ducks per site; Stott and Olson, 1973), and overall waterfowl abundance at our sites was more than 30 times less than that reported at the Jamaica Bay Wildlife

Table 3a - Habitat characteristics of waterfowl wintering sites in Narragansett Bay, RI, USA, 2001-2003

\begin{tabular}{|c|c|c|c|c|c|c|}
\hline Site & LATD & AREA & SHRL & PREM & PREC & HUNT \\
\hline Allen Harbor & 37.306 & 37.4 & 0.0022 & 24,032 & 1924 & 3.5 \\
\hline Apponaug Cove & 41.492 & 43.7 & 0.0018 & 108,534 & 29,017 & 1.0 \\
\hline Barrington River & 44.025 & 16.6 & 0.0020 & 99,600 & 21,726 & 1.0 \\
\hline Bissel Cove & 32.943 & 30.6 & 0.0024 & 100,189 & 26,358 & 4.0 \\
\hline Bonnet Point & 28.180 & 68.8 & 0.0008 & 52,117 & 147,171 & 1.0 \\
\hline Bristol Harbor & 40.562 & 155 & 0.0008 & 84,565 & 21,312 & 1.0 \\
\hline Brenton Cove & 28.427 & 75.3 & 0.0010 & 29,896 & 51,945 & 1.0 \\
\hline Brush Neck Cove & 41.232 & 50.1 & 0.0025 & 140,236 & 27,023 & 1.0 \\
\hline Bullocks Cove & 45.032 & 51.2 & 0.0016 & 79,267 & 8980 & 1.0 \\
\hline Colt State Park & 40.623 & 18.0 & 0.0025 & 173,099 & 13,988 & 2.5 \\
\hline Coggeshell Cove & 39.255 & 18.7 & 0.0023 & 188,767 & 25,862 & 4.5 \\
\hline Fogland Point & 33.272 & 18.2 & 0.0016 & 604,221 & 9451 & 4.0 \\
\hline Greenwich Bay & 40.588 & 1204 & 0.0006 & 34,028 & 12,236 & 3.0 \\
\hline Greenwich Cove & 39.467 & 110 & 0.0012 & 52,909 & 47,141 & 1.0 \\
\hline Hull Cove & 27.787 & 26.7 & 0.0017 & 23,694 & 88,706 & 4.0 \\
\hline Kickemuit River & 42.621 & 224 & 0.0010 & 210,608 & 63,692 & 2.0 \\
\hline Mackerel Cove & 28.894 & 86.1 & 0.0008 & 4956 & 94,112 & 3.0 \\
\hline Nag Pond & 37.677 & 6.30 & 0.0065 & 174,928 & 6621 & 3.0 \\
\hline Nanaquaket Pond & 36.513 & 81.1 & 0.0010 & 156,922 & 19,927 & 1.0 \\
\hline Newport Harbor & 28.760 & 72.5 & 0.0013 & 28,746 & 9638 & 1.0 \\
\hline Passeonkquis Cove & 44.790 & 7.90 & 0.0038 & 192,150 & 583,427 & 3.0 \\
\hline Potter Cove & 38.572 & 39.9 & 0.0012 & 381,557 & 21,072 & 4.0 \\
\hline Potowomut River & 39.286 & 68.7 & 0.0013 & 448,425 & 42,679 & 5.0 \\
\hline Portsmouth Cove & 37.775 & 132 & 0.0012 & 137,612 & 1684 & 3.0 \\
\hline Pawtuxet Cove & 45.322 & 27.4 & 0.0021 & 45,188 & 210,724 & 1.0 \\
\hline Sachuest Point & 28.547 & 60.0 & 0.0013 & $1,058,236$ & 19,885 & 1.0 \\
\hline Sakonnet Point & 27.205 & 51.4 & 0.0016 & 59,270 & 20,406 & 5.0 \\
\hline Sheffield Cove & 29.417 & 25.9 & 0.0004 & 183,671 & 1290 & 5.0 \\
\hline Warwick Cove & 41.475 & 46.4 & 0.0023 & 32,075 & 33,850 & 1.0 \\
\hline Warren River & 43.740 & 201 & 0.0010 & 233,044 & 40,037 & 1.0 \\
\hline Watchemoket Cove & 48.038 & 28.8 & 0.0018 & 126,323 & 39,499 & 1.0 \\
\hline Wickford Harbor & 34.523 & 166 & 0.0019 & 30,834 & 18,667 & 2.0 \\
\hline
\end{tabular}

LATD, distance of the site in nautical miles from $41^{\circ} \mathrm{N}$ latitude; AREA, water area of the site in hectares; SHRL, index of shoreline configuration; PREM, energetic content of invertebrate mollusk prey in kcal per hectare; PREC, energetic content of invertebrate crustacean prey in kcal per hectare; HUNT, index of hunting activity. 


\section{Table 3b - Landscape characteristics of waterfowl wintering sites in Narragansett Bay, RI, USA, 2001-2003}

\begin{tabular}{|c|c|c|c|c|c|}
\hline Site & RESL & VEGL & BUFT & W/ED & WLAR \\
\hline Allen Harbor & 0.000 & 0.511 & 0.740 & 2.19 & 4.542 \\
\hline Apponaug Cove & 0.595 & 0.044 & 0.795 & 1.15 & 3.093 \\
\hline Barrington River & 0.688 & 0.268 & 0.764 & 0.00 & 0.002 \\
\hline Bissel Cove & 0.384 & 0.357 & 0.813 & 2.52 & 4.553 \\
\hline Bonnet Point & 0.715 & 0.000 & 0.254 & 0.00 & 0.001 \\
\hline Bristol Harbor & 0.248 & 0.063 & 0.308 & 1.14 & 9.690 \\
\hline Brenton Cove & 0.359 & 0.031 & 1.000 & 0.00 & 0.001 \\
\hline Brush Neck Cove & 0.534 & 0.386 & 0.861 & 1.16 & 3.559 \\
\hline Bullocks Cove & 0.414 & 0.215 & 0.811 & 0.52 & 1.638 \\
\hline Colt State Park & 0.018 & 0.076 & 0.000 & 22.25 & 20.049 \\
\hline Coggeshell Cove & 0.000 & 0.206 & 0.310 & 11.87 & 13.645 \\
\hline Fogland Point & 0.249 & 0.000 & 0.092 & 0.87 & 1.077 \\
\hline Greenwich Bay & 0.456 & 0.218 & 0.693 & 0.43 & 29.748 \\
\hline Greenwich Cove & 0.229 & 0.405 & 0.613 & 0.19 & 1.233 \\
\hline Hull Cove & 0.325 & 0.514 & 0.917 & 0.22 & 0.395 \\
\hline Kickemuit River & 0.362 & 0.179 & 0.511 & 2.71 & 33.354 \\
\hline Mackerel Cove & 0.649 & 0.259 & 0.552 & 0.09 & 0.492 \\
\hline Nag Pond & 0.011 & 0.213 & 0.332 & 40.86 & 11.924 \\
\hline Nanaquaket Pond & 0.361 & 0.114 & 0.335 & 1.37 & 6.956 \\
\hline Newport Harbor & 0.226 & 0.170 & 0.711 & 0.00 & 0.001 \\
\hline Passeonkquis Cove & 0.333 & 0.265 & 0.793 & 10.32 & 5.698 \\
\hline Potter Cove & 0.000 & 0.412 & 0.542 & 3.33 & 7.476 \\
\hline Potowomut River & 0.421 & 0.179 & 0.812 & 2.36 & 10.086 \\
\hline Portsmouth Cove & 0.274 & 0.090 & 0.238 & 1.23 & 7.823 \\
\hline Pawtuxet Cove & 0.645 & 0.132 & 0.857 & 0.45 & 0.635 \\
\hline Sachuest Point & 0.003 & 0.762 & 0.571 & 1.09 & 3.442 \\
\hline Sakonnet Point & 0.041 & 0.110 & 0.219 & 0.00 & 0.001 \\
\hline Sheffield Cove & 0.162 & 0.221 & 0.417 & 6.91 & 9.217 \\
\hline Warwick Cove & 0.336 & 0.045 & 0.911 & 12.38 & 32.903 \\
\hline Warren River & 0.486 & 0.109 & 0.574 & 0.86 & 10.750 \\
\hline Watchemoket Cove & 0.105 & 0.130 & 0.194 & 0.37 & 1.085 \\
\hline Wickford Harbor & 0.383 & 0.222 & 0.686 & 3.79 & 33.596 \\
\hline
\end{tabular}

Refuge, Long Island, NY, USA (7322 ducks per site; Burger et al., 1984). These differences may be to some extent attributed to the urban setting of Narragansett Bay; however, there may also be differences attributed to seasonal and yearly changes in waterfowl numbers. Surrounding land use was not reported for the New Hampshire habitats, but they were not near any large urban centres. The Jamaica Bay sites were located within the Jamaica Bay Wildlife Refuge, which, while in relatively close proximity to New York City, is an undeveloped area where waterfowl are protected. The mean waterfowl density for the Narragansett Bay estuary (39 birds per square kilometer; McKinney, 2004) is comparable to Boston Harbor, MA, USA, an urban estuary located $110 \mathrm{~km}$ to the north (36 birds per square kilometer; TASL Online: http://www.gis.net/ szendeh/tasl.htm).

We detected more waterfowl at upper bay sites (i.e., sites at higher latitude) compared to those at the mouth of the Bay. Upper bay sites tend to be better protected from prevailing winter winds and from wave action because of the buffering effect of neighbouring land, and waterfowl may seek better protected sites to minimize the energetic costs of thermoregulation (Bennett and Bolen, 1978; Jorde et al., 1984;
Brodsky and Weatherhead, 1985). In Narragansett Bay, human population density is highest in the upper Bay, and hunting is often prohibited by state regulations in those areas. Ducks may favour these protected habitats and this behavior may mitigate to some extent any negative effects of residential development (e.g., increases in pedestrian and vehicular traffic, noise from pets) around these more densely inhabited sites.

Habitat models explained some of the variation in waterfowl abundance and species richness, particularly for rocky headland species. Our correlation coefficients were within the range of those reported for the abundance of brent geese Branta bernicla and Eurasion wigeon Anas penelope (Percival et al., 1996) and several marsh duck species in managed versus non-managed wetlands (Gordon et al., 1998) with habitat structure. Habitat characteristics included in the models varied for the different species assemblages, but for the most part the best habitat models were consistent with what is known of the winter habitat requirements of waterfowl. For example, except for shallow cove and rocky headland species, all abundances decreased with hunting activity, which agrees with previous studies of the effects of hunting disturbance 
Table 4 - Best habitat and landscape models for species richness and abundance of waterfowl assemblages wintering at Narragansett Bay, RI, USA sites, 2001-2003

\begin{tabular}{|c|c|c|c|}
\hline $\begin{array}{l}\text { Species assemblages } \\
\text { Model type }\end{array}$ & $\Delta \mathrm{AIC}_{\mathrm{c}}{ }^{\mathrm{a}}$ & $R^{2}$ & Best model \\
\hline \multicolumn{4}{|l|}{ All waterfowl } \\
\hline Habitat & 6.521 & 0.26 & $-104-42.2($ HUNT) + 11.0 (LATD) \\
\hline Landscape & 0.000 & 0.44 & $8.34-54.8($ HUNT) + 13.5 (LATD) -434 (RESL) - 9.37 (W/ED) \\
\hline \multicolumn{4}{|l|}{ Shallow cove } \\
\hline Habitat & 5.345 & 0.26 & $-28.2+2.63(\mathrm{HUNT})+1.22(\mathrm{LATD})+2.55 \times 10^{-5}(\mathrm{PREM})-4504(\mathrm{SHRL})$ \\
\hline Landscape & 0.000 & 0.27 & $-32.0+2.79(\mathrm{HUNT})+1.23(\mathrm{LATD})+2.69 \times 10^{-5}(\mathrm{PREM})-4517(\mathrm{SHRL})+5.42(\mathrm{BUFT})$ \\
\hline \multicolumn{4}{|l|}{ Rocky headland } \\
\hline Habitat & 3.570 & 0.23 & $53.4+0.49(\mathrm{HUNT})-1.59(\mathrm{LATD})+5.82 \times 10^{-5}(\mathrm{PREM})$ \\
\hline Landscape & 0.000 & 0.49 & $70.5+2.26(\mathrm{HUNT})-1.62$ (LATD) $+4.11 \times 10^{-5}(\mathrm{PREM})-32.2$ (RESL) \\
\hline \multicolumn{4}{|l|}{ Open water } \\
\hline Habitat & 6.934 & 0.13 & $-8.11-13.7$ (HUNT) + 4.89 (LATD) \\
\hline Landscape & 0.000 & 0.35 & $-81.7-22.2(\mathrm{HUNT})+6.28$ (LATD) -267 (RESL) -5.23 (W/ED) \\
\hline \multicolumn{4}{|l|}{ Marsh } \\
\hline Habitat & 0.482 & 0.17 & $14.4-10.9$ (HUNT) + 1.49 (LATD) \\
\hline Landscape & 0.000 & 0.18 & $26.2-10.5$ (HUNT) + 1.35 (LATD) - 34.3 (VEGL) \\
\hline \multicolumn{4}{|l|}{ Species richness } \\
\hline Habitat & 4.279 & 0.27 & $7.39-0.67($ HUNT $)+3.96 \times 10^{-6}(\mathrm{PREM})$ \\
\hline Landscape & 0.000 & 0.36 & $6.76-0.72(\mathrm{HUNT})+2.68 \times 10^{-6}(\mathrm{PREM})+4.48(\mathrm{VEGL})$ \\
\hline
\end{tabular}

Best models are those with the lowest Akaike Information Criterion corrected for small sample sizes (AIC). See Table 2 for a full list and description of candidate habitat and landscape variables. Species included in waterfowl assemblages are listed in Table 1.

a $\Delta \mathrm{AIC}_{\mathrm{c}}=\Delta \mathrm{AIC}_{\mathrm{ci}}-\operatorname{minAIC}_{\mathrm{c}}$.

Table 5 - Relative importance of habitat characteristics in regression models explaining species richness and abundance of waterfowl assemblages at wintering sites in Narragansett Bay, RI, USA, 2001-2003

\begin{tabular}{lccccc} 
Species & LATD & AREA & SHRL & PREM & PREC \\
\hline All waterfowl & 0.791 & 0.302 & 0.240 & 0.358 & 0.442 \\
Shallow cove & 0.791 & 0.241 & 0.609 & 0.250 & 0.482 \\
Rocky headland & 0.519 & 0.239 & 0.736 & 0.276 & 0.240 \\
Open water & 0.598 & 0.273 & 0.272 & 0.291 & 0.303 \\
Marsh ducks & 0.421 & 0.289 & 0.306 & 0.366 \\
Species richness & 0.318 & 0.232 & 0.849 & 0.258 \\
\hline
\end{tabular}

The relative importance is the sum of Akaike weights over all of the candidate models in which the variable occurred. See Table 2 for a description of habitat variables.

Table 6 - Relative importance of landscape characteristics in regression models explaining species richness and abundance of waterfowl assemblages at wintering sites in Narragansett Bay, RI, USA, 2001-2003

\begin{tabular}{llllll} 
Site & RESL & VEGL & BUFT & W/ED & WLAR \\
\hline All waterfowl & 0.859 & 0.248 & 0.240 & 0.754 & 0.309 \\
Shallow cove & 0.314 & 0.323 & 0.328 & 0.384 & 0.302 \\
Rocky headland & 0.457 & 0.281 & 0.324 & 0.708 & 0.309 \\
Open water & 0.857 & 0.263 & 0.253 & 0.298 & 0.290 \\
Marsh ducks & 0.316 & 0.355 & 0.297 & 0.343 \\
Species richness & 0.453 & 0.607 & 0.281 & 0.240 \\
\hline
\end{tabular}

The relative importance is the sum of Akaike weights over all of the candidate models in which the variable occurred. See Table 2 for a description of the habitat variables.

(Madsen, 1998a,b). Shallow cove species were represented primarily by bufflehead Bucephala albeola, and we noticed during several surveys that bufflehead would often not respond to hunting activity near their feeding sites. Bufflehead may not be as actively hunted as other North American waterfowl (collectively $1.1 \%$ of the annual harvest from 1966 to 1990; 
Baldassarre and Bolen, 1994, p. 330). Because hunting activity is included in all models, it is not possible to determine its importance relative to other habitat characteristics.

Because of the variability in the characteristics included in the models of different species assemblages, we used relative importance to determine which characteristics may be influencing habitat use. Habitat characteristics with the highest relative importance included site location (LATD), shoreline configuration and mollusc prey density (Table 5). Waterfowl abundance may increase with site latitude (higher latitude sites are located near the head of the estuary, in the inner Bay) because of the lack of hunting activity at these locations. Other factors, such as prey abundance or protection from exposure to waves or wind, may also influence the use of sites further inland. Rocky headland species are an exception: their numbers decrease with latitude because most rocky headlands are located near the mouth of the Bay at lower latitudes. In this case, availability of suitable prey may override the benefits gained from inland sites for these species. Previous studies of the food habits of wintering waterfowl (e.g., Nilsson, 1970; Gauthier, 1993; Gordon et al., 1998; Fischer and Griffin, 2000) have shown that prey energy density of benthic invertebrates may be an important determinant of habitat use for shallow cove, open water, and rocky headland species. Abundance of all species decreased with shoreline configuration, or the degree of convolution of the shoreline (i.e., increasing water-land interface). The importance of the boundary between two habitat types has been demonstrated for many species, and in our case a higher degree of shoreline configuration may increase exposure of waterfowl to land-based predators (Blackburn et al., 1999; Van Wilgenburg et al., 2001; Smith et al., 2004; but see Paton, 1994).

Including landscape characteristics improved the models for waterfowl abundance and species richness. Based on differences in Akaike weights $\left(\Delta \mathrm{AIC}_{\mathrm{c}}\right)$, models showed most improvement when landscape characteristics were added for all waterfowl and open water species, and least improvement for marsh ducks. This suggests that landscape setting may be influencing habitat use of wintering waterfowl in Narragansett Bay. Again using relative importance to compare among species assemblages, we found that surrounding residential land, surrounding vegetated land, and wetland edge most strongly influenced habitat use. The abundance of most species was positively correlated with the amount of vegetated land surrounding a site (VEGL), and negatively correlated with the amount of residential land (RESL). The abundance of all waterfowl decreased with higher residential land use, which may indicate a tendency to avoid areas in close proximity to human activity. Increased residential development and urbanisation has been shown to influence breeding bird species diversity and species composition (Blair, 1996; Jokimaki and Kaisanlahti- Jokimaki, 2003; Melles et al., 2003; Salvati, 2003), but few studies have examined changes in abundance with increasing development. Traut and Hostetler (2004) reported higher than expected abundances of wading birds, marsh birds, and ducks along developed shorelines in central Florida, but attributed changes to differences in vegetation rather than human disturbance.

The abundance of all waterfowl decreased with increasing wetland edge. We used wetland edge as a surrogate for the amount of undeveloped water-land edge at a site, and expected increased wetland edge would result in an increase in waterfowl abundance by providing protection from exposure and an undeveloped buffer from human activity (Kristan et al., 2003). However, increased wetland edge may also increase exposure of waterfowl to land-based predators. Waterfowl abundance increased with an increasing proportion of vegetated land (i.e., open grassland, shrub, brush, and forested areas) surrounding our sites. Vegetated land near wintering areas may provide important uninhabited buffer for waterfowl that mitigates the effects of human activity in the surrounding watershed, particularly when vegetated land comprises the upland terrestrial border of wetlands. Previous studies have suggested that surrounding vegetated land may enhance wetland wildlife habitat value (Golet and Larson, 1974; Burke and Whitfield, 1995; Semlitsch, 1998).

In summary, we identified best-fit habitat and landscape models to describe habitat use by wintering waterfowl in Narragansett bay, and found variability in the characteristics included in the models for different species assemblages. Our models identified several habitat and landscape characteristics that may be influencing the distribution of wintering waterfowl in Narragansett Bay, and should be considered when developing conservation strategies for these species. Additionally, our results suggest that landscape setting may be influencing habitat use by waterfowl in this urban estuary. For example, we found that nearby residential development was the most important landscape characteristic explaining waterfowl abundance in three of our six models, which suggests that indirect human activity may be influencing waterfowl distribution in this urban setting. This could have important implications for the management and conservation of coastal waterfowl habitat in other urban areas. If human disturbance does limit habitat availability, then areas that are subject to these disturbances may need to be devalued in some way to account for their reduced ability to support wintering waterfowl. This ultimately means that habitat objectives for waterfowl may need to be increased by some amount to account for their reduced value. However, our results should be interpreted with caution because (1) the waterfowl-habitat relationships presented here are correlative and do not imply cause and effect, (2) the correlations are weak, possibly in part a result of our small sample size, and (3) our study sites are characterized by relatively low waterfowl densities. Future studies will be needed to address these concerns: for example, larger scale studies of waterfowl habitat use encompassing habitats in both urban and undisturbed areas may provide insights into regional patterns of habitat use. Additionally, our results suggest that waterfowl use of habitats within a residential or urban setting may be confounded by limits on hunting imposed in these areas. Apponaug Cove, a site where hunting is prohibited, had the second highest waterfowl abundance despite having a high proportion of residential development within a $100 \mathrm{~m}$ radius of the site. Waterfowl may be willing to tolerate some degree of human activity adjacent to a habitat in exchange for not having to contend with hunting disturbance. Further studies will also be needed to investigate the impact of residential development on habitat utilisation in the context of direct human disturbance, such as hunting activity, to help in 
establishing conservation priorities for waterfowl wintering in urban estuarine habitats.

\section{Acknowledgements}

We thank H. Burnell, K. Bannick and B. Timm for their assistance with field data collection. We also thank G. Cicchetti, J. Grear, and E. Schneider who provided comments on the manuscript. C. Allin provided insights into waterfowl hunting patterns in Narragansett Bay. Mention of trade names or commercial products does not constitute endorsement or recommendation. Although the research described in this article has been funded wholly by the US Environmental Protection Agency, it has not been subjected to Agency-level review. Therefore, it does not necessarily reflect the views of the Agency. This is the Office of Research and Development, National Health and Environmental Effects Research Laboratory, Atlantic Ecology Division Contribution No. AED-05-017.

\section{R E F E R E N C E S}

Adamik, P., Kornan, M., Vojtek, J., 2003. The effect of habitat structure on guild patterns and the foraging strategies of insectivorous birds in forests. Biologia (Bratislava) 582, 275-285.

Ambrose, R.F., Meffert, D.J., 1999. Fish-assemblage dynamics in Malibu Lagoon, a small, hydrologically altered estuary in southern California. Wetlands 19, 327-340.

Anderson, J.R., Hardy, E.E., Roach, J.T., Whitmer, R.W., 1976. A land use and land cover classification system for use with remote sensor data. Geological Survey Professional Paper 964. US Geological Survey, Washington, DC, USA.

Anderson, D.R., Link, W.A., Johnson, D.H., Burnham, K.P., 2001. Suggestions for presenting the results of data analyses. Journal of Wildlife Management 65, 373-378.

Baldassarre, G.A., Bolen, E.G., 1994. Waterfowl Ecology and Management. Wiley, New York.

Bellrose, F., 1980. Ducks, Geese, and Swans of North America, third ed. Stackpole Books, Harrisburg, PA.

Bennett, A.F., Ford, L.A., 1997. Land use, habitat change and the conservation of birds in fragmented rural environments: a landscape perspective from the Northern Plains, Victoria, Australia. Pacific Conservation Biology 3, 244-261.

Bennett, J.W., Bolen, E.G., 1978. Stress response in wintering Green-winged Teal. Journal of Wildlife Management 42, 81-86.

Blackburn, T.M., Gaston, K.J., Quinn, R.M., Gregory, R.D., 1999. Do local abundances of British birds change with proximity to range edge? Journal of Biogeography 26, 493-505.

Blair, R.B., 1996. Land use and avian species diversity along an urban gradient. Ecological Applications 6, 506-519.

Brodsky, L.M., Weatherhead, P.J., 1985. Variability in behavioral response of wintering black ducks to increased energy demands. Canadian Journal of Zoology 63, 1223-1226.

Burger, J., Trout, J.R., Wander, W., Ritter, G.S., 1984. Jamaica Bay studies VII: Factors affecting the distribution and abundance of ducks in a New York estuary. Estuarine Coastal and Shelf Science 19, 673-689.

Burke, V.J., Whitfield, G.J., 1995. Terrestrial buffer zones and wetland conservation: a case study of freshwater turtles in a Carolina Bay. Conservation Biology 9, 1365-1369.

Burnham, K.P., Anderson, D.R., 2002. Model selection and multimodel inference: a practical information-theoretic approach, second ed. Springer-Verlag, New York, p. 488.
Chavez-Ramirez, F., Slack, R.D., 1995. Differential use of coastal marsh habitats by nonbreeding wading birds. Colonial Waterbirds 18, 166-171.

Christiansen, J.E., Low, J.B., 1970. Water requirements of waterfowl marshlands in northern Utah. Utah Division of fish and Game Publication 69-12, 108.

Clausen, P., Madsen, J., Percival, S.M., O'Connor, D., Anderson, G.Q., 1998. Population development and changes in winter site use by the Svalbard light-bellied brent goose, Branta bernicla hrota 1980-1994. Biological Conservation 84, 157-165.

Clergeaua, P., Crocia, S., Jokimaki, J., Kaisanlahti-Jokimaki, M.L., Dinettic, M., 2006. Avifauna homogenisation by urbanisation: analysis at different European latitudes. Biological Conservation 127, 336-344.

Collopy, M.W., Bildstein, K.L., 1987. Foraging behavior of northern harriers wintering in southeastern salt and freshwater marshes. Auk 104, 11-16.

Colwell, M.A., 1993. Shorebird community patterns in a seasonally dynamic estuary. Condor 95, 104-114.

Conley, D.J., Kaas, H., Mohlenberg, F., Rasmussen, B., Windloff, J., 2000. Characteristics of Danish estuaries. Estuaries 23, 820-837.

Conomy, J.T., Collazo, J.A., Dubovsky, J.A., Fleming, W.J., 1998. Dabbling duck behavior and aircraft activity in coastal North Carolina. Journal of Wildlife Management 62, 1127-1134.

Davidson, N., Rothwell, P., 1993. Disturbance to waterfowl on estuaries. Wader Study Group Bulletin 68, 1-106.

Elkins, N., Lynch, B.M., 1997. Waterfowl counts on the Tay Estuary, 1985-1995. Scottish Birds 19, 36-54.

Esselink, P., Zijlstra, W., Dijkema, K.S., van Diggelen, R., 2000. The effects of decreased management on plant-species distribution patterns in a salt marsh nature reserve in the Wadden Sea. Biological Conservation 93, 61-76.

Evans, D.M., Day, K.R., 2001. Does shooting disturbance affect diving ducks on large shallow lakes? A case study on Lough Neagh, Northern Ireland. Biological Conservation 98, 315-323.

Fischer, J.B., Griffin, C.R., 2000. Feeding behavior and food habits of wintering Harlequin Ducks at Shemya Island, Alaska. Wilson Bulletin 112, 318-325.

Fletcher, R.J., Koford, R.R., 2002. Habitat and landscape associations of breeding birds in native and restored grasslands. Journal of Wildlife Management 66, 1011-1022.

Fowler, J., Cohen, L., Jarvis, P., 1998. Practical Statistics for Field Biology. Wiley, New York.

Gauthier, G., 1993. Bufflehead (Bucephala albeola). In: Poole, A., Gill, F. (Eds.), The Birds of North America, 67. The Birds of North America, Inc., Philadelphia, PA.

Golet, F.C., Larson, J.S., 1974. Classification of freshwater wetland in the glaciated Northeast. US Fish and Wildlife Resource Publication 116, 56.

Gordon, D.H., Gray, B.T., Perry, R.D., Prevost, M.B., Strange, T.H., Williams, R.K., 1989. South Atlantic coastal wetlands. In: Smith, L.M., Pederson, R.L., Kaminski, R.M. (Eds.), Habitat Management for Migrating and Wintering Waterfowl in North America. Texas Tech University Press, Lubbock, TX, pp. 57-92.

Gordon, D.H., Gray, B.T., Kaminski, R.M., 1998. Dabbling duck-habitat associations during winter in coastal South Carolina. Journal of Wildlife Management 62, 569-580.

Goudie, R.I., Ankney, C.D., 1988. Patterns of habitat use by sea ducks wintering in southeastern Newfoundland. Ornis Scandinavica 19, 249-256.

Hinrichsen, D., 1996. Coasts in crisis. Issues in Science and Technology 12, 39-47.

Jokimaki, J., Kaisanlahti- Jokimaki, M.L., 2003. Spatial similarity of urban bird communities: a multiscale approach. Journal of Biogeography 30, 1183-1193.

Jorde, D.G., Krapu, G.L., Crawford, R.D., Day, M.A., 1984. Effects of weather on habitat selection and behavior of Mallards wintering in Nebraska. Condor 86, 258-265. 
Kennish, M.J., 2002. Environmental threats and environmental future of estuaries. Environmental Conservation 29, 78-107.

Klemm, D.J., Lewis, P.A., Fulk, F., Lazorchak, J.M., 1990. Macroinvertebrate field laboratory methods for evaluating the biological integrity of surface waters. US Environmental Protection Agency, EPA-600-4-90-030, Environmental Monitoring and Support Laboratory, Cincinnati, $\mathrm{OH}$.

Krasnov, Y.V., Gavrilo, M.V., Chernook, V.I., 2004. Distribution patterns of birds over the Pechora Sea area according to aerial survey data. Zoologicheskii Zhurnal 83, 449-458.

Kristan, W.B., Lynam, A.J., Price, M.V., Rotenberry, J.T., 2003. Alternative causes of edge-abundance relationships in birds and small mammals of California coastal sage shrub. Ecography 26, 29-44.

Le V Dit Durell, S.E.A., Stillman, R.A., Triplet, P., Aulert, C., Ono Dit Biot, D., Bouchet, A., et al, 2005. Modelling the efficacy of proposed mitigation areas for shorebirds: a case study on the Seine estuary, France. Biological Conservation 123, 67-77.

Madsen, J., 1995. Impacts of disturbance on migratory waterfowl. Ibis 137, S67-S74.

Madsen, J., 1998a. Experimental refuges for migratory waterfowl in Danish wetlands. I. Baseline assessment of the disturbance effects of recreational activities. Journal of Applied Ecology 35, 386-397.

Madsen, J., 1998b. Experimental refuges for migratory waterfowl in Danish wetlands. II. Tests of hunting disturbance effects. Journal of Applied Ecology 35, 386-397.

Madsen, J., Fox, A.D., 1995. Impact of hunting disturbance on waterbirds - a review. Wildlife Biology 1, 193-207.

Melles, S., Glenn, S., Martin, K., 2003. Urban bird diversity and landscape complexity: Species-environment associations along a multiscale habitat gradient. Conservation Ecology 7 , 271-279.

McKinney, R.A., 2004. Habitat relationships of waterfowl wintering in Narragansett Bay. Rhode Island Natural History Survey Bulletin 11, 3-6.

McKinney, R.A., Glatt, S.M., McWilliams, S.R., 2004. Allometric length-weight relationships for benthic prey of aquatic wildlife in coastal marine habitats. Wildlife Biology 10, 241-249.

Michael, J.M., Opler Haecker, P.A., Doran, P.D., 1998Status and Trends of the Nation's Biological Resources, vol. 1. Washington, DC, US Geological Survey. 454 pp.

Miller, J.R., Cale, P., 2000. Behavioral mechanisms and habitat use by birds in a fragmented agricultural landscape. Ecological Applications 10, 1732-1748.

Neves, R.J., Angermeier, P.L., 1990. Habitat alteration and its effects on native fishes in the upper Tennessee River system, east-central U. S.A. Journal of Fish Biology 37 (Suppl. A), 45-52.

Nilsson, L., 1970. Food seeking activity of south Swedish diving ducks in the non-breeding season. Oikos 21, 145-154.

Owen, M., 1993. The UK shooting disturbance project. Wader Study Group Bulletin 68, 35-46.

Paton, P.W.C., 1994. The effect of edge on avian nest success: how strong is the evidence? Conservation Biology 8, 17-26.
Paul, J.F., Copeland, J.L., Charpentier, M., August, P.V., Hollister, J.W., 2003. Overview of GIS applications in estuarine monitoring and assessment research. Marine Geodesy 26, 63-72.

Percival, S.M., Sutherland, W.J., Evans, P.R., 1996. A spatial depletion model of the responses of grazing wildfowl to the availability of intertidal vegetation. Journal of Applied Ecology 33, 979-992.

Perry, M.C., Deller, A.S., 1996. Review of factors affecting the distribution and abundance of waterfowl in shallow water habitats of Chesapeake Bay. Estuaries 19, 272-278.

Ravenscroft, N.O.M., Beardall, C.H., 2003. The importance of freshwater flows over estuarine mudflats for wintering waders and wildfowl. Biological Conservation 113, 89-97.

Robertson, A.I., 1979. The relationship between annual production : biomass ratios and lifespans for marine macrobenthos. Oecologia 38, 193-202.

Roman, C.T., Jaworski, N., Short, F.T., Findlay, S., Warren, R.S., 2000. Estuaries of the northeastern United States: habitat and land use signatures. Estuaries 23, 743-764.

Roth, R.R., 1976. Spatial heterogeneity and bird species diversity. Ecology 57, 773-782.

Salvati, L., 2003. Distribution and relative abundance of wintering birds in a Mediterranean urban area: the influence of habitat variables. Biota 4, 91-100.

Sanderson, G.C., 1980. Conservation of waterfowl, third ed.. In: Bellrose, F.C. (Ed.), Ducks, Geese and Swans of North America Stackpole Books, Harrisburg, PA, pp. 43-58.

Semlitsch, R.D., 1998. Biological delineation of terrestrial buffer zones for pond-breeding salamanders. Conservation Biology 12, 1113-1119.

Smith, L.M., Haukos, D.A., Prather, R.M., 2004. Avian response to vegetative pattern in playa wetlands during winter. Wildlife Society Bulletin 32, 474-480.

Soderstrom, B., Svensson, B., Vessby, K., Glimskar, A., 2001. Plants, insects and birds in semi-natural pastures in relation to local habitat and landscape factors. Biodiversity and Conservation 10, 1839-1863.

Stott, R.S., Olson, D.P., 1973. Food-habitat relationship of sea ducks on the New Hampshire coastline. Ecology 36, 468-477.

Traut, A.H., Hostetler, M.E., 2004. Urban lakes and waterbirds: effects of shoreline development on avian distribution. Landscape and Urban Planning 69, 69-85.

Van Wilgenburg, S.L., Mazerolle, D.F., Hobson, K.A., 2001. Patterns of arthropod abundance, vegetation, and microclimate at boreal forest edge and interior in two landscapes: Implications for forest birds. Ecoscience 8, 454-461.

Vanderklift, M.A., Jacoby, C.A., 2003. Patterns in fish assemblages 25 years after major seagrass loss. Marine Ecology Progress Series 247, 225-235.

Wetzel, R.G., 1975. Limnology. W.B. Saunders, Philadelphia, PA.

West, A.D., Goss-Custard, J.D., Stillman, R.A., Caldow, R.W.G., le V dit Durrell, S.E.A., McGrorty, S., 2002. Predicting the impacts of disturbance on shorebird mortality using a behaviour-based model. Biological Conservation 106, 319-328. 